\title{
Jurisprudence of Minority Rights: The Changing Contours of Minority Rights
}

\author{
Kheinkor Lamarr \\ Ph.D. Scholar, Jawaharlal Nehru University, New Delhi, India \\ kheinkorlamarr@gmail.com
}

\begin{abstract}
Questions concerning minority rights has long been of international consequence and is at the centre of many academic, legal and political debates. Identity claims of minority groups have been recognised and deemed worthy of protection. It is significant to note that nonetheless even today minority issues tend to occasion anxiety amongst people and States. It is therefore necessary to have jurisprudential understanding of minority rights. This will enable us to gain clarity on questions of the nature of minority rights and the various challenges revolving around them. The paper has viewed claims and rights of minorities from the stand-point of international law and human rights and in doing so has charted out the historic progression of minority rights. It further studies the present day issues of the inter-relationship between minority rights and refugees and migrants. It also examines the ever increasing demands for the inclusion of various categories like gender and children under the minority rights regime.

KEYWORDS: Minority Rights, History of Minority Rights, International Law, Human Rights
\end{abstract}

\section{Introduction}

The protection and rights of minority groups have long been of international consequence and are at the centre of academic and political debates. Identity claims of minority groups have been recognised and deemed worthy of protection. It is significant 
to note that nonetheless even today minority issues tend to occasion anxiety amongst people and States. States have long held the view of minority groups as a divisive force, an anomaly within the State and a threat that may destabilise the State or a region. Historically the instances of ethnic tensions in Eastern and Central Europe and more recently the horrific incidents of the Rwandan genocide and the conflict in Sri Lanka between the Sinhalese majority and Ceylon Tamil minority are prominent examples of situations associated with or faced by minorities. Even today religious intolerance and denial of linguistic rights form prime areas of discrimination against minorities. It is therefore necessary to have a jurisprudential understanding of minority rights that will enable us to gain clarity on questions of the nature and evolution of minority rights. This paper to that end 1) traces the beginnings of minority claims and rights up till the present, 2) discusses the Post World War II situation and contemporary minority rights and 3) addresses the inter-relationship between minority rights and migrants and refugees and examines the ever increasing demands for the inclusion of various categories like gender in the list of beneficiaries of minority rights.

It may be noted that any discussion upon the question of minority groups necessarily pose a demand for a definition of the term 'minority'. To date however no satisfactory definition of the term 'minority' has been arrived at which is acceptable to all. It is noteworthy that no consensus over a definition has been reached even in international documents that deal with issues of minority protection. This may be attributable to the fact that the concept is fluid and dependant on different social and political factors in different historical contexts. A discourse on the possible definition to the term 'minority' is a subject-matter which requires to be discussed at length and it will not be possible to be dealt with in the space of the present paper. Hence, for the purposes of this paper minority will be understood as per the United Nations (UN) usage. Article 27 of the International Covenant on Civil and Political Rights, (ICCPR) in the absence of a definition has qualified the term minority as "ethnic, religious and linguistic minorities" (The United Nations General Assembly 1966 art. 27).

\section{A Historical Account of Minority Rights and Protection}

In a historical context there exist two main narratives pertaining to the origins of minority protection. One narrative suggests that the current issues of minority rights can be traced no further than the nineteenth century to instances like the Conference of London, 1830, where France demanded assurance for Catholics and Greece accepted to grant equal political rights without distinction of religion to her subjects (Rosting $1923,644)$ and the League of Nations mechanism on minority protection. The second 
narrative on the other hand traces the roots of minority rights back to the seventeenth century reforms made as a response to protect religious minorities. For example, the Treaty of Westphalia, 1648, wherein the Protestant German population were granted religious rights and The Treaty of Paris, 1763, signed by Great Britain, France and Spain, for the protection of Roman Catholics in the Canadian territories which were ceded by France (Lerner 1991, 7-22).

However, there is yet a third narrative to the history of minority rights to a time that precedes the modern State system and goes back to the middle ages and possibly even prior to it (Oestreich 1999, 110). An example of this is St. Louis' pledge to protect the Maronite Christians in the Holy Land in the year 1250, a promise which continued to be periodically renewed by the French monarchs. Another case in point is the situation prevalent in the Ottoman Empire where non-Muslims who though comprised a numerical majority were effectively in status minorities, were allowed their own religious laws (Sigler 1983, 70). The empire categorized each religious community as a separate nation and the system was referred to as the 'millet system' and implemented in the year 1453 by Sultan Mehmet II (Kucukcan 2003, 480-481; Yildiz 2007, 793). This system at first established with intentions of gaining the support of Christian religious leaders in conquered territories was progressively extended to other minorities like the Jews and Armenians.

From the three narratives it is apparent that the earliest examples of minority rights protection were based on religion (Rosting 1923, 642). Religion has been the oldest source of collective identity and the exercise of religious beliefs are to a large extent social practices defining attire, food habits, language, etc. giving it the potential for diversity dilemmas. In the past conflicts based on religion have included the persecution of early Christians by Romans that persisted up until Christianity itself became the official religion of the Roman Empire in 380 AD (The Edict of Thessalonica, 27 February 380 AD recognised Nicene Christianity as the only authorized State religion of the Roman Empire). For individuals their religious identity stood out against their identity as French, Turk, and Egyptian. Consequently, religious minorities living in European territories during the medieval times like the Jews were placed under a variety of restrictions and excluded from many systems.

The impetus to provide protection to religious minorities were typically motivated by the need to resolve violent conflicts like the ones amongst Catholics and Protestants in Christian Europe and situations leading to the ceding of territories from one State to the other. The demands of ethnic and linguistic minorities as opposed to religious minorities came into the picture at a much later date. It was towards the latter half of the eighteenth century when the concept of popular sovereignty materialised that 
ethnic attachments became important. This is not to say that ethnic identities had not mattered in the past but that it had not mattered to the same degree of import as it came to be during the eighteenth century. Reasons attributable for this change was that political authority in the past had not necessarily vested upon an idea of shared ethnicity, but by the eighteenth and early nineteenth century authority became located in the people. In the past the political authority's claim to rule was based on the idea of divine right but slowly it became necessary to have a bond between the political rulers and with the people (Preece 2005, 137). As such, ethnic characteristics gained prominence and with it came ethnic diversities. Most States observed these ethnic diversities as potential problems towards territorial integrity and responded to this perceived problem with various minority policies ranging from recognition to the complete elimination of diversity (Preece 2005, 138). The Congress of Vienna in 1815 is one of the early example of minority protection which took on the form of ethnic protections. The Polish treaty which was signed at the congress is one such illustration which recognized the right of Poles to retain their own culture and institutions (Oestreich 1999,111). The present-day minority issues dealing with religious, ethnic and linguistic minorities that we are most familiar with may be traced to the three congresses of Vienna (1814-15), Paris (1856), and Berlin (1878) (Thornberry 1991, 25-37). These congresses encompassed minority protection provisions in treaties establishing rights and security of populaces that were to be transferred to a foreign sovereignty (Fink 1995, 197).

\subsection{Nationalism and its Impact on Modern Minority Rights}

Nationalism has been considered by many to be the foundation of modern minority rights (Sigler 1983, 72). Though the terms 'nation' and 'nationalism' are at times used synonymously there is a distinction between the two. Nationalism denotes a set of beliefs about the nation. The most distinctive character of nationalism is the belief that the nation is the only goal worth pursuing (Grosby 2005, 1-6). The latter half of the eighteenth and the early nineteenth century saw increased scholarly attention given to the idea of nationalism in Europe. The idea of nationalism was enflamed by the writings and speeches of intellectuals like Gottfried von Herder, Johann Gottlieb Fichte, Friedrich Jahn and Giuseppe Mazzini who emphasized upon the importance of language and cultural heritage. Herder (1744-1803) who first voiced these matters is credited with the development of the idea of 'Volk' which means 'people' or 'nation'. This theory of Volk meant a community which was bound together through bloodties and was characterised with a particular culture, language customs and religion. According to him the most natural State comprised of a community with its own 
national character and multinational States were simply mock reproductions devoid of inner life (Musgrave 1997, 5). Herder's theory gained prominence and was picked up by later scholars and by nineteenth century the idea of nation-states defined by ethnic and linguistic character spread throughout Central and Eastern Europe. This in turn spearheaded a condition which saw the international community become progressively susceptible to outbreaks of internal violence which threatened to spread beyond State boundaries (Fink 1995, 197). Minority groups began increasingly to be seen as anomalies who were incapable to have a nation of their own or have the ability to join the dominant majority in building national character. Minority discontent and dissatisfaction became one of the most unsettling forces in international relations especially in the context of minority claims in Eastern Europe.

A kaleidoscopic redistribution of sovereign power took place post-world war I. The nearly simultaneous disintegration of the Habsburg, Ottoman, Hohen-zollern and Romanov Empires together with Woodrow Wilson's rhetoric of self-determination established the platform for creation of new States and the formation of national, cultural, religious, and linguistic minority communities and subsequent minority related problems (Fink 1995, 197; Sigler 1983, 72).

The international legal agenda after World War I accordingly was dominated by national minority groups. The idea of nationalism having gained tremendous ground led for demands by minority groups for equal treatment with majority populations or independent statehood. The insistence of nationalists was that every nation must have their own State. These sentiments were seen in Slavic minorities, the Irish, Jews etc. who were amongst a few of the many groups asking for their own State or to join their brethren in already established States. The most dominant and prevailing understanding of nationalism came to mean one in which the boundaries of the State were to correspond to that of the nation. This understanding was even accepted by the post-war decision makers headed by Woodrow Wilson (Wippman 1997, 599). The Paris Peace Conference of 1919 (also known as The Versailles Peace Conference) to a large extent re-arranged and redrew State boundaries in Eastern and Central Europe on the principle of one nation one State. But it was impossible to ensure to every 'nation' a State of their own due to historical, geographical and political constraints. The result was that about 20-30 million people found themselves continuing in, or cast anew in the role of national minorities (Wippman 1997, 599). The triumphant States of World War I who met at the conference were consequently particularly concerned about the treatment of minorities. This concern stemmed not from any altruistic desire to protect minorities but from the apprehension that the newly drawn boundaries might perpetuate-or even accentuate-tensions between majorities and minorities. This 
anxiety was further highlighted by the fact that the Paris Peace Conference created a predicament by on one hand proclaiming ethnic nationalism to be the underlying principle of the State whilst at the same time assigning to States a heterogeneous nationality (Heyking 1927,34). This unease over the minority situation was therefore sought to be addressed through a minority protection mechanism under the League of Nations. It was hoped that the League System would help reduce the significance of territorial boundaries for the concerned groups (Wippman 1997, 600).

\subsection{The Minority Rights and the League of Nations}

Minority rights as we understand them under International Law was first systematically put into place following a series of treaties that were drafted at the end of the First World War within the League of Nations framework. Early on in the deliberations Wilson had made efforts to place a clause on minority protection in the League Covenant itself. However these efforts proved to be a failure (Fink 1995, 198). These series of treaties which came to be known as the minority treaties included the five special minorities treaties that bound Poland, the Serbo-Croat-Slovene State, Romania, Greece and Czechoslovakia; the special minorities clauses in the treaties of peace with four of the defeated central powers Austria, Turkey, Hungary and Bulgaria; the five general declarations made by Albania, Lithuania, Latvia, Estonia and Iraq on their admission to the League; the special declaration made by Finland in relation to the Aland Islands after it had been admitted to the League; and the treaties relating to the territories of Danzig, Memmel and Upper Silesia (Rosting 1923, 641-660; Fink 1995, 204).

The minority treaties of the League of Nations are of significance since they were the forerunner to all future efforts made and envisaged to guarantee minority rights postWorld War II. These Minority Treaties created legal obligations upon the signatory States on behalf of racial, linguistic, ethnic and religious minorities. The Paris Peace Conference insisted that the defeated or newly reconfigured States accept a set of treaty obligations designed to protect the interests of minority group members. The Minority treaties granted political and religious equality to minorities as well as some special rights to minority groups (Fink 1995, 197).

The minority treaties were different in form to all other past efforts which had been made for the protection of minority groups. The principle difference was based on the enforcement procedure. While earlier the guarantor for the minority protection provisions were the Great Powers now it came to be entrusted to the League of Nations instead (Rosting 1923, 647). Further, the treaties provided that any disputes that arose 
in connection to the minority provisions could be submitted to the Permanent Court of International Justice (PCIJ) or the World Court. This was done with the purpose of removing minority issues from the political domain to a legal one.

The League's Minority Regime nevertheless reaped much criticism even at the outset. The major criticisms were that the minorities and their advocates were excluded from having any direct access to the league system. The League system had a set of rights for minority protection but they bound only a small number of States. Thus the League was unable to establish any form of universal jurisprudence for claims and rights of racial, linguistic or religious minorities wherever they may exist (Wippman, 1997,601). The element of discontent was also grounded on the fact that the treaties satisfied neither the States that were signatories to them nor the minority groups. The refusal to develop a universal system for protection of minorities led States who were bound by the minority treaties to feel it as an infringement of their sovereignty seeing the victorious States not similarly bound by minority rights provisions. The minority groups viewed the protections as derisory and inadequate, and resented their lack of legal standing as corporate entities to directly challenge the League when there were treaty violations. The League's minorities system was fundamentally to a large extent a peace-making and conciliatory process.

Despite the criticism to the League System several disputes concerning minorities and the minority treaties were brought before the Council of the League of Nations and a few even went on to be brought up before PCIJ. These cases today form an important source of jurisprudence for understanding minority related claims.

One of the landmark case was Minority Schools in Albania, Advisory Opinion of 1935. This was one of the last cases brought before the PCIJ that involved questions of minority protection. In this case the difficulties involving minority protection arose when the Albanian Government in 1923 made its intentions known to abolish the right to maintain and establish private schools. Following such intentions moves were made to secularize education ultimately resulting in the amendment to the Constitution of 1928, in 1933 by which private schools were abolished. This situation resulted in petitions to the League of Nations on behalf of minorities like the Greek Catholics. During the course of the proceeding the Albanian government argued that the abolition of the private schools in Albania was a general measure applicable to both the majority and minority groups. They contended that compelling Albania to respect private minority schools would lead to the creation of privilege in favour of the minority groups. The PCIJ however responded to these contentions by holding that equality in law does prohibit discrimination of any kind but equality in fact may encompass the necessity of differential treatment. The equality between the 
members of the majority and minority needs to be effective and genuine equality. The Court highlighted the object of the Minority Treaty was to preserve characteristics which distinguish a minority from the majority and satisfying any special needs of the minorities in their efforts to preserve their characteristics. It was the Court's opinion that there could exist no true equality between the majority and minority if the minorities were dispossessed of their own institutions and forced to forsake that which establishes the very essence of their being as a minority.

It may be seen that the PCIJ whilst interpreting the Minority Treaties interpreted them in a broad sense and rejected narrow constructions and gave due regard to the underlying intent of the treaties (Acquisition of Polish Nationality, Advisory Opinion, 1923). The various cases considered by the PCIJ involving the minority treaties are still relevant today though the minority treaties are no longer applicable and form a good part of minority rights jurisprudence. In fact cases like the Minority Schools in Albania are still extensively referred to not only for their ideas on minority protection but also general principles of law.

\section{Post-World War II and Contemporary Minority Rights}

Post-World War II though there were a number of proposals for the inclusion of some version of the minority protection system, the framers of the United Nations however chose not to do so. One of the reasons given for this discontinuity was the belief in the failure of the League's minority protection mechanism. The second and more overpowering reason was the perceived threat to the integrity and national sovereignty of the State if minority protections were given. Leaders like Roosevelt who had a prominent say in the Post World War II situation felt that there was no requirement for special protection of minority groups (Sigler 1983, 77). The reasoning behind this viewpoint was that these leaders were familiar only with situations of discrimination against groups (like the Blacks) who sought integration into society. They were unable to comprehend situations of groups who might want to protect and preserve their distinctive identity, culture, language, etc.

The post- World War II approach therefore came to be based on individual rights. The argument advanced was that the broad spectrum of individual rights would by itself protect minority claims and interests. Such arguments also had underlying philosophical basis in the Liberal Theory that gave primacy to the individual as against any conception of the group or community. Both the United Nations Charter (The United Nations 1945) and the Universal Declaration of Human Rights (The United 
Nations 1948) therefore make no mention of minority rights. Though there wasn't a complete neglect of minority concerns as evidenced by the establishment of the United Nations Sub-commission on Prevention of Discrimination and Protection of Minorities established in 1946 minority rights simply was no longer considered high on the international agenda.

Events such as the fall of the Berlin Wall on 9 November, 1989 and the violent breakup of Yugoslavia during the early 1990's radically transformed such attitudes. It led to both States and International Organisations renewing their focus on the question of minorities. The United Nations has gradually made headway into minority issues which include the drafting of Article 27 of the ICCPR and the UN Declaration on Minorities (The United Nations General Assembly 1992). At a regional level Europe has seen the most development in this field and the drafting and adoption of the Framework Convention on National Minorities (Council of Europe 1995) is regarded as a big step in the advancement of minority rights.

The drafting of Article 27 of the ICCPR, a provision which for the first time specifically mentioned minority rights was a landmark event with respect to Minority Rights. This particular provision is considered as a milestone in minority protection as it is a legally binding provision and constitutes as applicable hard law. The article recognises the right of persons belonging to "ethnic, religious or linguistic minorities" to profess their own religion, use their language and to revel in their own culture (The United Nations General Assembly 1966 art. 27). The language of the article suggests that the rights enshrined are individual rights and does not have a group or collective rights character. In other words they are individual rights that allows a person to engage in particular activities in community with others.

This particular provision has still drawn in several criticisms. The criticisms include the failure of the provision to provide and definition of the term minority and also that it was declaratory in nature with minimum rights (Dinstein 1976, 118). It was also censured as being insufficient in addressing all the complexities inherent to issues concerning minority rights (Kymlicka 2005, 28). Also the framing of the rights in terms of individual rights rather than group rights and that the provision was a negative provision (Shaw 1997, 485) sparked an assortment of scholarly debates.

The opinions and questions regarding nature of the provision have been varied and it was only at a later date that certain clarifications were provided in the Human Rights Committee's (HRC) General Comment No. 23 (United Nations Human Rights Committee 1994). An important elucidation made by the General Comment is that Article 27 places positive obligations on States in furtherance of protection 
of minorities. The General Comment No 23 states "Although article 27 is expressed in negative terms, that article, nevertheless, does recognize the existence of a "right" and requires that it shall not be denied. Consequently, a State party is under an obligation to ensure that the existence and the exercise of this right are protected against their denial or violation." (United Nations Human Rights Committee 1994, para. 6.1).

With regards to the nature of the rights under Article 27, the General Comment No 23 in para. 3.1 states that Article 27 guarantees rights to individuals. This was ostensibly done so as to not confuse the right to self-determination with any of the rights guaranteed under Article 27. This statement effectively shows that elements of groups characteristic may not be associated with minority rights.

Further jurisprudence on the nature and scope of minority rights has developed through the views expressed by the Human Rights Committee (HRC) while examining complaints submitted to them under Article 27. One of the key areas of the HRC's jurisprudence on Article 27 has been the interpretation of the normative content of the concept of culture. For example in Sandra Lovelace v Canada (1981), the challenge was with regards to a Canadian law which deprived an Indian woman of her Indian status and her right to reside in at an Indian Reserve on her marriage to a non-Indian man. The HRC determined that people who are born and raised on a reserve and have maintained and further want to maintain ties to that community and have access to their native culture and language should be considered part of that minority group within the meaning of Article 27. The HRC has also broadly interpreted in Lubicon Lake Band v Canada (1990), that Article 27 included an individual's right to enjoy their own culture in community with others and that this would even include a particular way of life associated with the use of land resource or an economic activity. It must be noted that HRC's interpretations of Article 27 has maintained that the protection of minority rights is an individual right and no collective element has been introduced.

After the breakdown of the League of Nations Mechanism and the coming up of the human rights regime minority rights appears to have seamlessly been woven into the fabric of human rights law. This situation raises questions as to whether bringing in minority rights under the canon of human rights law adequately deal with all minority issues. There exists an extensive amount of controversy and disagreement concerning this issue within the literature of rights language (Preece $1997,17)$. The reasons for such questions arise because it is felt that the traditional human rights standards are insufficient in dealing with challenges associated with minority rights. For instance, the emphasis which is being placed on the cultural uniqueness of minority groups lead minority claims to be viewed synonymously 
as cultural rights. Such an understanding then restricts minority claims to only cultural rights and fails at recognizing other varied claims which include economic as well as political claims. Even in the case of cultural claims traditional human rights as such are unable to deal with more nuanced issues like that of recognition of languages in parliament and courts, the drawing up of internal boundaries based on the population of cultural minorities etc. As such it is suggested that it is necessary to further study the normative status of minority rights and they be deliberated as a distinct category.

\section{Existing Challenges}

The United Nations qualification of the term 'minority' includes only ethnic, religious and linguistic minority groups (national minorities are included as per the UN Declaration on Minorities). No other groups be it race or gender have been included. But due to the absence of a definition per se the road for the proposals of including various recipients for minority rights has been paved. The proposals have been based on the belief that groups or communities like the differently abled are similarly discriminated against and face prejudice from a dominant majority group. There also exists questions on the extent of application of minority rights to non-citizens and subsequently their inter-relationship with migrants and refugees.

\subsection{Beneficiaries to Minority Rights}

One of the biggest concerns with respect to beneficiaries of minority rights stem from gender groups. Foremost amongst them is the question of whether or not women be included under the umbrella of minority groups and subsequently avail all rights associated to them. In most societies women and men are in general numerically equal in number. But the status of women as a secondary or lesser to men have led most to associate them as a minority group. There have been many international legal instruments that have advocated for the greater rights of women, significant amongst them is the Convention on the Elimination of All Forms of Discrimination against Women (The United Nations 1979). However, proponents continue to argue for women to be categorised as a minority due to discrimination based on sex. Nonetheless the question as to whether or not women be included as a minority groups should not be based on whether women have been made objects of prejudices or discrimination but whether they can satisfactorily be characterised as a group category of people to 
sufficiently be able to constitute a minority group (Sigler 1983, 5). Currently, however, in addition to women the case of the Lesbian, Gay, Bisexual and Transgender People community (LGBT) is also being proffered as a group constituting sexual minorities. This community of gender variant people have come to be understood especially in Europe to have intrinsic characteristics that can be identifiable as a group.

Similarly children are likewise considered by many to be a minority group. Children are understood to be the most vulnerable, powerless and easily discriminated members of society. It is usually seen that being a child can often lead to being in a state of disempowerment. But in the context of minority rights what is significant is not whether children as a group be regarded as a minority but to situations wherein a child also belongs to a member of other dis-empowered groups. This is because it would lead to them experiencing double discrimination. For example a children who belong to an ethnic minority group would on one hand be vulnerable and easily discriminated against for simply being a child and on the other hand, the isolation inherent in the minority groups they belong to could lead to the reinforcement of these discriminations.

Another group who seek minority status are the differently abled. There was and still is a distinct lack of interest shown towards individuals with disabilities. These individuals not only face discrimination in society but are more likely to leave school early or become unemployed and live in extreme poverty (McDonald, Keys and Balcazar. 2007, 146). The Disability rights movement has however contributed to a large extent in bringing to light the problems and discrimination faced by such individuals. They are also the ones who promote the view of disabled people as a minority who are deprived by society due to their physical impairments. Activists of disability rights have started to use a minority rights based approach to further the disability rights movement and gain fresh insights and perspective. For instance, the deaf community see themselves as a linguistic and cultural minority and not as differently abled (McQuigg 2003, 368; Charrow and Wilbur 1975, 353).

\subsection{The Inter-relationship between Minority Rights and Migrants and Refugees}

Rights have generally been considered to be vested upon individuals who are also the citizens of nation-States. Most human rights instruments nevertheless provide that States have an obligation to protect the rights of all human beings subject to or under their jurisdictions, with the exception of certain political rights. It is however seen that though international human rights law envisions rights to all, be they migrants, refugees or stateless persons, it is usually seen that non-citizens face difficulties in accessing their rights. This can largely be attributed to nation-states dependency upon 
the ideas of nationality and citizenship. In the context of minorities and minority rights this situation gives rise to questions involving the application of minority rights to non-citizens, migrants and refugees

General Comment No. 23, in para 5.1 and 5.2 clarified that State parties are under an obligation to respect and ensure the application of article 27 ICCPR to everyone within their territory and jurisdiction and that such individuals need not be citizens of the State (United Nations Human Rights Committee 1994).

In practice however, non-citizen minorities may still face problems in accessing such rights. States may in their domestic definitions of minorities place a restrictive citizenship criterion or even not recognise the existence of minority groups like in France. Under the Framework Convention on National Minorities as well the protection is for the benefit of 'national minorities' leaving behind concerns over non-citizen minorities. As Hannah Arendt points out that despite the impression of human rights being considered as universal it is only through the membership of specific political communities built around the nation-state are rights recognised in any meaningful sense (Arendt 1979, 299).

With respect to migrants the traditional international law notion is that they be omitted from the protection afforded to minorities. Further, when migrants leave their country of origin with the intention of resettling elsewhere the immigrant integration schemes of those countries also fail to respect the immigrants' rights as a minority group. This non recognition of ethnic, linguistic or cultural differences amongst the migrants groups is also an outflow of typical aspects of the nation-state, which theorizes that migrants should abandon their particular cultural identity and conform to the majority culture (Ringelheim 2010, 111). By the 1980s, this notion had begun to be increasingly challenged by supporters of multiculturalism who argued that States should respect cultural differences even of individuals belonging to immigrant populations. But there is a propensity of State laws and policies to distinguish 'national minorities' from migrant populations (Kymlicka 2008, 7). This distinction has resulted in the formation of 'old minorities' for the country's home minorities and 'new minorities' for new migrant populations like temporary guest workers, permanent immigrants, asylum seekers, etc. As such 'new minorities' are generally not provided with rights similar to those of national minorities and in case that they are accorded minority rights they are normally in line with integration policies and not accommodation (Kymlicka 2008, 8).

In the case of the refugee populations as well they are regularly faced with discrimination, intolerance and opposition and are seen by citizens of States to be the 
cause of the States instability especially in light of recent terror activities. Though in the international scene there exists a distinct category of refugee law activists involved in the protection of refugees and reduction of discrimination faced by them advocate that refugees should also be allowed to maintain their distinct identities. Efforts are made to utilise a minority rights based approach towards their protection.

It must be noted at this juncture that many refugee populations belong to ethnic, religious or linguistic minorities. Also in many cases the discrimination and persecution faced by such minorities was the reason that lead to them fleeing their home States and becoming refugees in the first place. The most contemporary examples of minority populations fleeing persecution, are the Syrian Refugees who are also comprised of people from religious minority groups and the Rohingyas who are an ethnic minority group.

The conundrum that emerges from this situation is whether or not such refugee population should fall within the minority rights ambit. The fact that there exists an entirely different arena of international law which is present to deal with refugees makes most want to keep these two categories distinct from one another. But what can be ascertained is that whether we want to or not questions of minority rights and refugees do intersect and it is therefore necessary to acknowledge this overlap between them.

\section{Conclusion}

Minority Rights and the protection of minority groups may be traced back to the middle ages and possibly beyond. But the contemporary conception of minority rights has its beginnings only post-World War I with the establishment of the League of Nations mechanism of minority groups protection. Minority Rights first developed as protection towards religious minorities and it was at a much later date that ethnic and linguistic minorities came into the picture. The formation of nation-states and the spread of the ideas of nationalism have played an essential role and have had a profound impact on the advancement of minority claims and rights. After a brief period of discontinuity in the minority rights regime post-World War II there has been progressive developments in the field of minority rights. However this development has been intertwined into the fabric of Human Rights framework raising questions into the normative status of minority rights.

Though there has been considerable jurisprudential development in the field of minority rights there still persists a variety of concerns both old and new. The question of definition for the term 'minority' continues to trouble scholars and 
practitioners of law. New challenges comprise the proposals to include various groups as the beneficiaries to minority rights and the application of minority rights to non-citizens, refugees etc. These existing challenges call for a larger debate on the rights discourse and the usage of particular rights regime to advocate the rights of discriminated individuals and groups.

\section{References}

Arendt, Hannah. 1979. The Origins of Totalitarianism. San Diego: Harcourt Brace Jovanovich.

Charrow, Veda R., and Ronnie B. Wilbur. 1975. "The Deaf Child as a Linguistic Minority." Theory Into Practice 14(5):353-59. http://www.jstor.org/stable/1475829.

Council of Europe. 1995."Framework Convention for the Protection of National Minorities." Council of Europe Treaty Series 157. Strasbourg: Council of Europe.

Dinstein, Y. 1976. "Collective Human Rights of Peoples and Minorities." International and Comparative Law Quarterly 25(1): 102-120.

Fink, Carol. 1995. “The League of Nations and the Minorities Question." World Affairs 157, no. 4:197-205. http://www.jstor.org/stable/20672435.

Grosby, Steven. 2005. Nationalism: A Very Short Introduction. UK: Oxford University Press.

Heyking, Baron. 1927. "The International Protection of Minorities. The Achilles' Heel of the League of Nations." Transactions of the Grotius Society 13:31-51.

Kucukcan, Talip. 2003. "State, Islam, and Religious Liberty in Modern Turkey: Reconfiguration of Religion in the Public Sphere." Brigham Young University Law Review 2:475-506.

Kymlicka, Will. 2005. "A European Experiment in Protecting Cultural Rights," Human Rights Dialogue $12(2): 28-31$

Kymlicka, Will. 2008. "The Internationalization of Minority Rights." International Journal of Constitutional Law 6(1):1- 32. https://doi.org/10.1093/icon/mom032.

Lerner, Nathan. 1991. Group Rights and Discrimination in International Law. Dordrecht/ Boston/London: Martinus Nijhoff.

McDonald, K.E., Keys, C.B. and F.E. Balcazar. 2007."Disability, Race/Ethnicity and Gender: Themes of Cultural Oppression, Acts of Individual Resistance." American Journal of Community Psychology 39:145-161.

McQuigg, Karen. 2003. "Are the deaf a disabled group, or a linguistic minority? Issues for librarians in Victoria's public libraries." The Australian Library Journal 52(4): 367-377. doi:10.1080/00049670.2003.10721582

Musgrave, Thomas D. 1997. Self-Determination and National Minorities. Oxford: Clarendon Press. 
Oestreich, Joel E. 1999.“Liberal Theory and Minority Group Rights.” Human Rights Quarterly $21(1): 108-132$.

Preece, Jennifer J. 1997."Minority Rights in Europe: From Westphalia to Helsinki." Review of International Studies 23(1):75-92.

Preece, Jennifer J. 2005. Minority Rights: Between Diversity and Community. Cambridge, UK: Malden MA Polity Press.

Ringelheim, Julie. 2010. "Minority Rights in a Time of Multiculturalism-The Evolving Scope of the Framework Convention on the Protection of National Minorities." Human Rights Law Review 10(1): 99-128.

Rosting, Helmer. 1923. "Protection of Minorities by The League of Nations." The American Journal of International Law 17(4): 641-660.

Shaw, M.N. 1997. "Peoples, Territorialism and Boundaries", European Journal of International Law 3(1): 478-507.

Sigler, J.A. 1983. Minority Rights: A Comparative Analysis, Westport, Connecticut. London. England: Greenwood Press.

The United Nations General Assembly. 1966. "International Covenant on Civil and Political Rights." United Nations Treaty Series 999 (December):171.

The United Nations General Assembly. 1992. Declaration on the Rights of Persons Belonging to National or Ethnic, Religious and Linguistic Minorities.

The United Nations Human Rights Committee. 1994. CCPR General Comment No. 23: Article 27 (Rights of Minorities).

The United Nations. 1945. "Charter of the United Nations." 1 United Nations Treaty Series XVI

The United Nations. 1948. Universal Declaration of Human Rights.

The United Nations. 1979. "Convention on the Elimination of All Forms of Discrimination against Women." United Nations Treaty Series 1249: 13.

Thornberry, Patrick. 1991. International Law and the Rights of Minorities. Oxford: Clarendon Press.

Wippman, David. 1997. "The Evolution and Implementation of Minority Rights." Fordham Law Review 66(2):597-626.

Yildiz, Ilhan. 2007. "Minority Rights in Turkey." Brigham Young University Law Review (3): 791-812. 